\title{
PENGARUH TINGKAT PENDIDIKAN, MOTIVASI, DAN KOMPENSASI TERHADAP KINERJA PEGAWAI DI BRI CABANG SEMARANG AHMAD YANI
}

\author{
Sopi, Zumrotun Nafiah \\ Program Studi Manajemen dan Akuntansi STIE SEMARANG
}

\begin{abstract}
Education, motivation and compensation are important things that can improve performance. This study aims to explain whether there is an influence of education, motivation and compensation on employee performance. So that through the results of this study it is expected to be a reference for leaders in managing the organization. In this study there are three independent variables namely education, motivation and compensation and one dependent variable is employee performance. At present it is in the era of industrial revolution 4.0, which is marked by; big data / giant data, internet of think, labor knowledge, and long life education. Since the beginning of the life of mankind to an infinite period, it is largely determined by the mastery of science and technology. Science and technology can not be separated from the progress of education level. Education is the base of all changes both individually, as well as countries. Employee performance is determined by the education that is owned, as high as education, the higher the performance and vice versa. The population in this study are BRI CAB employees, SEMARANG A-YANI, 60 people and all of them are sampled. The results of the analysis using SPSS 23 program statistical tools obtained multiple linear regression equation $Y=0.505 X 1+0.175 X 2+0.408 X 3$ The results of multiple linear regression equations show that there is a positive and significant influence between education on employee performance at BRI CAB. A YANI SEMARANG ( $t$ count test 6.314> $t$ table 0.05), motivation towards employee performance at BRI CAB. A YANI SEMARANG (tcount 2,160> $t$ table 0,05), and compensation for employee performance at BRI CAB. A YANI SEMARANG ( $t$ test 5.108> ttable 0.05). While together (simultaneously) the influence of education, motivation and compensation has an effect on and significant on the performance of employees at BRI CAB. A YANI SEMARANG (count = 44,692> ftabel $=0.05)$. The influence of the two research variables is very strong with a correlation value of $69.0 \%$ for employee performance at BRI CAB. A YANI SEMARANG is influenced by the motivation and compensation education of the remaining $31.0 \%$ of the employees' performance at BRI CAB. A YANI SEMARANG is influenced by other variables that affect employee performance.
\end{abstract}

\section{Keywords; Performance, Education Level, Motivation, and Compensation}

\begin{abstract}
ABSTRAK
Pendidikan, motivasi dan kompensasi adalah hal yang cukup penting yang dapat meningkatkan kinerja. Penelitian ini bertujuan untuk menjelaskan apakah ada pengaruh pendidikan, motivasi dan kompensasi terhadap kinerja karyawan. Sehingga melalui hasil penelitian ini diharapkan dapat menjadi rujukan para pimpinan dalam mengelola organiasi. Dalam penelitian ini terdapat tiga variabel bebas yaitu pendidikan, motivasi dan kompensasi dan satu variabel terikat yaitu kinerja karyawan. Pada saat ini berada pada era revolusi industry 4.0, yang ditandai oleh; big data/data raksasa, internet of think, labour knowledge,
\end{abstract}


dan long life education. Sejak awal kehidupan umat manusia sampai masa yang tak terbatas, sangat ditentukan oleh kemampuan penguasaan iptek. Iptek tidak dapat terlepas dengan kemajuan tingkat pendidikan. Pendidikan merupakan pangkal segala perubahan baik secara individu, kelompok maupn Negara. Kinerja pegawai angat ditentukan oleh pendidikan yang dimiliki, seakin tinggi pendidikan semakin tinggi kinerja dan sebaliknya.Populasi dalam penelitian ini adalah karyawan BRI CAB,SEMARANG A-YANI sejumlah 60 orang dan semuanya dijadikan sampel. Hasil analisis dengan alat bantu statistik program SPSS 23 diperoleh persamaan regresi linier berganda $Y=0,505 X_{1}+0,175 X_{2}+0,408 X_{3}$ Hasil persamaan regresi linier berganda menunjukan bahwa ada pengaruh yang positif dan signifikan antara pendidikan terhadap kinerja karyawan di BRI CAB. A YANI SEMARANG (uji thitung 6,314 > $\mathrm{t}_{\text {tabel }}$ 0,05), motivasi terhadap kinerja karyawan di BRI CAB. A YANI SEMARANG (uji thitung 2,160 > $\mathrm{t}_{\text {tabel }}$ 0,05), dan kompensasi terhadap kinerja karyawan di BRI CAB. A YANI SEMARANG (uji thitung 5,108 > t tabel 0.05). Sedangkan secara bersamasama (simultan) pengaruh pendidikan, motivasi dan kompensasi berpengaruh dan signifikan terhadap kinerja karyawan di BRI CAB. A YANI SEMARANG $\left(\mathrm{f}_{\text {hitung }}=44,692>\mathrm{f}_{\text {tabel }}=\right.$ 0,05). Pengaruh kedua variabel penelitian sangat kuat dengan nilai kolerasi $69,0 \%$ untuk kinerja karyawan di BRI CAB. A YANI SEMARANG dipengaruhi oleh pendidikan motivasi dan kompensasi selebihnya 31,0\% kinerja karyawan di BRI CAB. A YANI SEMARANG dipengaruhi oleh variabel lain yang mempengaruhi kinerja Pegawai.

\section{Kata kunci: Kinerja, Tingkat Pendidikan, Motivasi, dan Kompensasi}

\section{PENDAHULUAN}

\section{Latar Belakang Masalah}

Setiap perusahaan akan berusaha meningkatkan dan mengembangkan perusahaan dengan mengadakan berbagai kegiatan guna meningkatkan kinerja para karyawan. Adanya kegiatan tersebut, diharapkan perusahaan akan mencapai tujuan perusahaan yaitu untuk memperoleh keuntungan (profit oriented). Secara umum, pengelolaan sumber daya manusia dimaksudkan untuk meningkatkan kinerja perusahaan, sehingga pembentukan sumber daya manusia yang memiliki kemampuan merupakan suatu keharusan. Oleh sebab itu, pengelolaan dan pendayagunaan sumber daya manusia menjadi perhatian untuk dikembangkan secara maksimal.

Kinerja adalah hasil kerja yang dapat dicapai oleh seseorang atau sekelompok orang dalam suatu organisasi, sesuai dengan wewenang dan tanggung jawab masing-masing dalam rangka mencapai tujuan organisasi yang bersangkutan secara legal, tidak melanggar hukum, dan sesuai dengan moral maupun etika (Rachmawati dalam Hidayah 2016). Hasil kerja karyawan dipengaruhi oleh faktor internal dan faktor eksternal. Faktor internal merupakan faktor yang berhubungan dengan sifat-sifat seseorang, sikap, kepribadian, sifat fisik, 
keinginan atau motivasi, umur, jenis kelamin, pendidikan, pengalaman kerja, latar belakang budaya, dan variabel-variabel personal lainnya. Faktor eksternal merupakan faktor-faktor yang mempengaruhi kinerja karyawan; lingkungan, kepemimpinan, tindakan-tindakan rekan kerja, jenis latihan dan pengawasan, sistem upah serta lingkungan sosial.

Oleh Hasbullah dalam Vioneta (2013) menyatakan bahwa "Pendidikan sering diartikan sebagai usaha manusia untuk membina kepribadiannya sesuai nilai-nilai kebudayaan dan masyarakat." Lebih lanjut Hasbullah dalam Vioneta (2013) menyatakan bahwa "Pendidikan adalah usaha yang dijalankan oleh seseorang atau kelompok orang lain agar menjadi dewasa atau mencapai tingkat hidup atau penghidupan yang lebih tinggi dalam arti mental."

Motivasi kerja merupakan keinginan yang terdapat dalam diri seseorang untuk melakukan suatu pekerjaan tertentu guna mencapai tujuan yang telah ditentukan oleh organisasi atau perusahaan, karena menurut Malayu dalam Vioneta (2013) motivasi berasal dari bahasa latin "Moreve" yang berarti dorongan dari dalam diri manusia untuk bertindak atau berperilaku. Pengertian motivasi tidak terlepas dari kata kebutuhan atau "needs" atau "want".

Motivasi kerja yang tinggi dapat meningkatkan kinerja pegawai, sesuai yang diungkapkan oleh Gibson dan Stoner dalam Sudarwan dalam Vioneta (2013) motivasi kerja merupakan alasan-alasan, dorongan-dorongan yang ada dalam diri manusia yang menyebabkan ia melakukan sesuatu atau berbuat sesuatu. Motivasi yang berbeda karena pengaruh baik faktor dari dalam diri maupun dari, hal ini menarik untuk dilakukan penelitian apakah memiliki pengaruh motivasi terhadap kinerja pegawai BRI cab. A. Yani.

Kompensasi menurut Melayu S.P. Hasibuan dalam Hidayah (2016), semua pendapatan yang berbentuk uang, barang langsung atau tidak langsung yang diterima karyawan sebagai imbalan jasa yang diberikan kepada perusahaan. Tujuan pemberian kompensasi antara lain adalah sebagai ikatan kerja sama, kepuasan kerja, pengendalian efektif, motivasi, stabilitas karyawan, dan disiplin.

Setiap karyawan mempunyai keinginan untuk mendapatkan kompensasi yang sesuai dengan harapan mereka. Apabila harapan tersebut terpenuhi, maka karyawan tersebut akan bersemangat dalam bekerja. Handoko dalam Hidayah (2016), menyatakan bahwa departemen personalia merancang dan mengadministrasikan kompensasi karyawan. Apabila kompensasi yang diberikan sesuai, karyawan lebih terpuaskan dan termotivasi untuk mencapai sasaran. 
Kompensasi menjadi sangat penting karena dengan kompensasi, individu dapat memenuhi kebutuhan baik itu kebutuhan primer, sekunder dan tertier. Pemenuhan kebutuhan-kebutuhan tersebut pada akhirnya ikut menentukan kualitas kerja.

Berdasarkan paparan diatas, maka dapat dirumuskan masalah penelitian:

1. Apakah terdapat pengaruh tingkat pendidikan terhadap kinerja pegawai di BRI cab. Semarang A. Yani?.

2. Apakah terdapat pengaruh motivasi terhadap kinerja pegawai di BRI cab. Semarang A. Yani?.

3. Apakah terdapat pengaruh kompensasi terhadap kinerja pegawai di BRI cab. Semarang A. Yani?

\section{KAJIAN TEORITIS}

\section{Kinerja Pegawai}

Kinerja (Performance) berarti prestasi kerja. Wibowo dalam Vioneta (2013) "Kinerja mempunyai makna yang lebih luas, bukan hanya menyatakan sebagai hasil kerja, tetapi juga bagaimana proses kerja berlangsung." Amstong dan Baron dalam Vioneta (2013), menyatakan "Kinerja merupakan hasil pekerjaan yang mempunyai hubungan kuat dengan tujuan yang strategis organisasi, kepuasan konsumen dan memberikan kontribusi ekonomi." Veithzal dalam Vioneta (2013) menyatakan bahwa "Kinerja merupakan perilaku nyata yang ditampilkan seorang sebagai prestasi kerja yang dihasilkan sesuai dengan perannya" Sedangkan Anwar dalam Vioneta (2013), "Hasil kerja secara kualitas dan kuantitas yang dicapai oleh seorang pegawai dalam melaksanakan tugasnya sesuai dengan tanggung jawab yang diberikan kepadanya." Marihot Tua Efendi dalam Hidayah (2016), kinerja merupakan hasil kerja yang dihasilkan oleh pegawai.

Kinerja tidak berdiri sendiri tapi berhubungan dengan kepuasan kerja dan kompensasi, keterampilan, kemampuan, keinginan dan lingkungan (Rivai dalam Hidayah 2016).

\section{Penilaian Kinerja}

Hani Handoko dalam Hidayah (2016) pengukuran kinerja adalah usaha untuk merencanakan dan mengontrol proses pengelolaan pekerjaan, sehingga dapat dilaksanakan sesuai tujuan yang telah ditetapkan. Penilaian prestasi kerja, merupakan proses mengevaluasi 
dan menilai prestasi kerja karyawan di waktu yang lalu dan prestasi kerja di waktu yang akan datang.

Dessler dalam Hidayah (2016), ada lima faktor dalam penilaian kinerja:

1. Prestasi pekerjaan;akurasi, ketelitian, keterampilan dan penerimaan keluaran.

2. Kuantitas pekerjaan, meliputi : volume keluaran dan kontribusi.

3. Kepemimpinan yang diperlukan;membutuhkan saran, arahan atau perbaikan.

4. Kedisiplinan; kehadiran ketepatan waktu.

5. Komunikasi; hubungan antar karyawan maupun dengan pimpinan.

Penilaian kinerja merupakan dasar yang digunakan dalam penentuan kompensasi. Penilaian kinerja (performance apprasial), merupakan faktor kunci guna mengembangkan satu organisasi secara efektif dan efisien. Handoko dalam Hidayah (2016) penilaian prestasi kerja, proses melalui mana organisasi-organisasi mengevaluasi atau menilai prestasi kerja karyawan. Manfaat penilaian prestasi kerja:

1. Perbaikan prestasi kerja,

2. Penyesuaian-penyesuaian kompensasi,

3. Kebutuhan pelatihan dan pengembangan,

4. Perencanaan dan pengembangan karier.

5. Penyimpangan proses staffing.

\section{Faktor-faktor yang mempengaruhi kinerja pegawai}

A. Kualitas kerja

Fahmi dalam Edduar (2015), Kualitas kerja adalah hasil yang diperolah oleh suatu organisasi baik organisasi profit oriented dan non profi oriented. Mangkunegara dalam Edduar (2015), Mengartikan kualitas kerja merupakan hasil kerja secara kualitas ataupun kuantitas yang dicapai seseorang dalam melaksanakan pekerjaannya sesuai dengan tanggung jawabnya.

Wibowo dalam Edduar (2015), Kualitas kerja adalah Suatu organisasi yang professional tidak akan mampu mewujudkan suatu manajemen kualitas kerja yang baik tanpa ada dukungan dari seluruh komponen perusahaan. Mangkunegara dalam Edduar (2015) Kualitas berarti sesuatu yang akan terus tumbuh dan berkembang bersama perubahan. Kualitas terbaik hanya mampu dihasilkan dari peningkatan kualitas kerja mutu kerja, dan penguatan budaya organisasi. 


\section{B. Kuantitas Kerja}

Wungu dan Brotoharsojo dalam Edduar (2015), "Quantity (kuantitas) adalah segala bentuk satuan ukuran yang terkait dengan jumlah hasil kerja dan dinyatakan dalam ukuran angka atau yang dapat dipadankan dengan angka". Wilson dan Heyyel dalam Edduar (2015), Quantity of Work, adalah jumlah kerja yang dilaksanakan oleh pegawai dalam suatu periode tertentu.

\section{Sikap Kerja}

Seseorang bisa memiliki ribuan sikap, tetapi dalam kehidupan organisasi difokuskan pada beberapa jenis sikap yang berkaitan dengan kerja. Robbins dalam Edduar (2015), sikap adalah pernyataan-pernyataan evaluatif baik yang diinginkan atau yang tidak diinginkan mengenai obyek, orang atau peristiwa. Tiga komponen sikap, antara lain: kognitif, afektif dan perilaku.

G.W Alport dalam Edduar (2015) sikap adalah kesiapan seseorang untuk bertindak. Seiring dengan pendapat G.W. Alport di atas Tri Rusmi Widayatun memberikan pengertian sikap adalah "keadaan mental dan syaraf dari kesiapan, yang diatur melalui pengalaman yang memberikan pengaruh dinamik atau terarah terhadap respon individu pada semua obyek dan situasi yang berkaitan dengannya".

Rakhmat dalam Edduar (2015) mengemukakan lima pengertian sikap, yaitu:

a. Sikap, kecenderungan bertindak, berpersepsi, berpikir, dan merasa dalam menghadapi objek, ide, situasi, atau nilai.

b. Sikap bukan sekedar rekaman masa lalu, tetapi juga menentukan apakah orang harus pro atau kontra terhadap sesuatu.

c. Sikap lebih menetap.

d. Sikap mengandung aspek evaluatif.

e. Sikap timbul dari pengalaman, bukan bawaan lahir, tetapi merupakan hasil belajar. Karena itu sikap dapat diperteguh atau diubah.

La Pierre dalam Edduar (2015), sikap sebagai suatu pola perilaku, tendensi atau kesiapan antisipatif, predisposisi untuk menyesuaikan diri dalam situasi sosial, atau sikap adalah respon terhadap stimuli sosial yang telah terkondisikan. Oleh Soetarno dalam Edduar (2015), sikap, pandangan atau perasaan yang disertai kecenderungan untuk bertindak. 
Untuk benar-benar memahami sikap perlu mempertimbangkan karakteristik secara fundamental. Ada tiga komponen yang membentuk sikap, yaitu; Kognitif (cognitive), Afektif (affective) dan konatif (conative), Konatif atau komponen perilaku dalam struktur sikap menunjukkan bagaimana perilaku yang berkaitan dengan obyek yang dihadapi (Notoatmodjo dalam Edduar 2015).

Tingkat Pendidikan

Pendidikan, oleh Hasbullah dalam Vioneta (2013), bahwa "Pendidikan sering diartikan sebagai usaha manusia untuk membina kepribadiannya sesuai nilai-nilai kebudayaan dan masyarakat." Menurut Undang-undang No. 20 tahun 2003 menyatakan bahwa pendidikan adalah "Usaha sadar dan terencana untuk mewujudkan suasana belajar dan proses pembelajaran agar peserta didik secara aktif mengembangkan potensi dirinya untuk memilki kekuatan spiritual, keagamaan, pengendalian diri, kepribadian, kecerdasan, akhlak mulia serta keterampilan yang diperlukan utuk dirinya, masyarakat, bangsa dan negara."

Jalur-Jalur Pendidikan

Menurut UU no 20 tahun 2003 Jalur pendidikan terdiri atas pendidikan formal, nonformal, dan informal yang dapat saling melengkapi dan memperkaya. Pendidikan dasar berbentuk Sekolah Dasar (SD) dan Madrasah Ibtidaiyah (MI) atau bentuk lain yang sederajat serta Sekolah Menengah Pertama (SMP) dan Madrasah Tsanawiyah (MTs), atau bentuk lain yang sederajat.

Perguruan tinggi dapat berbentuk akademi, politeknik, sekolah tinggi, institut, atau universitas. Perguruan tinggi berkewajiban menyelenggarakan pendidikan, penelitian, dan pengabdian kepada masyarakat. Perguruan tinggi dapat menyelenggarakan program akademik, profesi, dan/vokasi.

Jenis-Jenis Pendidikan

Jenis-jenis pendidikan oleh M.Ngalim Purwanto dalam Adhanari (2011) adalah sebagai berikut; Pendidikan Jasmani, Pendidikan Rohani, Pendidikan Kecakapan, Pendidikan Keagamaan (Pendidikan Kesusilaan, Pendidikan Keindahan dan Pendidikan Kemasyarakatan) 


\section{Motivasi}

Pengertian motivasi

Malayu dalam Vionita (2013), motivasi berasal dari bahasa latin "Moreve" yang berarti dorongan dari dalam diri manusia untuk bertindak atau berperilaku. Pengertian motivasi tidak terlepas dari kata kebutuhan atau "needs" atau "want". Stanford dalam Vionita (2013) motivasi, "Suatu kondisi yang menggerakkan manusia kearah tujuan tertentu." Sedangkan Terry dalam Vionita (2013), motivasi adalah " Keinginan yang terdapat pada diri seseeorang individu yang mendorongnya untuk melakukan perbuatan-perbuatan)."

Motivasi menurut Veithzal dalam Vionita (2013), "Serangkaian sikap dan nilai-nilai yang mempengaruhi individu untuk mencapai hal yang spesifik sesuai dengan tujuannya." Anwar dalam Vionita (2013) juga mendefinisikan motivasi, "Kondisi yang menggerakkan pegawai agar mampu mencapai tujuan." Suatu motivasi individu dapat timbul dari dalam diri individu (motivasi instrinsik) dan dapat timbul dari luar diri individu (motivasi ekstrinsik), keduanya mempunyai pengaruh terhadap perilaku dan kinerja.

\section{Kompensasi}

Kompensasi, sesuatu yang diterima karyawan sebagai imbalan jasa mereka terhadap perusahaan. Hani Handoko dalam Hidayah (2016) berpendapat bahwa kompensasi mencerminkan ukuran karya mereka di antara para karyawan. Mathis dan Jackson dalam Hidayah (2016) menyatakan bahwa salah satu cara untuk meningkatkan prestasi kerja, para karyawan adalah melalui kompensasi.

Hasibuan dalam Hidayah (2016) mengemukakan kompensasi, semua pendapatan yang berbentuk uang, barang langsung atau tidak langsung yang diterima karyawan sebagai imbalan atas jasa yang diberikan kepada perusahaan. Milkovich dan Newman dalam Hidayah (2016) menyatakan bahwa kompensasi berkenaan dengan segala bentuk balas jasa finansial dan pelayanan yang tangible (nyata), serta keuntungan yang diterima karyawan sebagai bagian dari suatu hubungan pekerjaan.

Menurut Rabindra dan Medonca dalam Hidayah (2016) kepuasan kompensasi adalah tingkat kepuasan terhadap semua bentuk return baik finansial maupun non finansial yang diterima karyawan karena jasa yang disumbangkan kepada perusahaan. Michael dan Harold dalam Hidayah (2016) menyatakan bahwa kepuasan kompensasi adalah Kepuasan Kerja terhadap kompensasi yang diterima dari perusahaan sebagai balas jasa atas kerja mereka. 
Mobley dalam Hidayah (2016), kepuasan kompensasi sebagai keadaan dimana harapan akan kompensasi sesuai dengan kenyataan. Dessler dalam Hidayah (2016), kompensasi karyawan adalah setiap bentuk pembayaran atau imbalan yang diberikan dan timbul dari dipekerjakannya.

Kompensasi berbentuk finansial berbentuk gaji, upah, bonus, komisi, asuransi karyawan, bantuan sosial karyawan, tunjangan, libur, atau cuti tetap dibayar, sedangkan dalam bentuk non finansial, berupa tugas menarik, tantangan tugas, tanggung jawab tuga peluang, pengakuan, lingkungan pekerjaan yang menarik (Anthony \& Govendarajan dalam Hidayah 2016).

\section{Jenis-jenis kompensasi}

Menurut Malayu Hasibuan (2008) secara garis besar membagi kompensasi menjadi tiga jenis, yaitu :

1. Kompensasi Langsung, gaji atau upah, yang dibayar secara tetap berdasarkan tenggang waktu yang tetap

2. Kompensasi Tidak Langsung, Pemberian di luar gaji atau upah tetap, dapat berupa uang atau barang.

3. Insentif, Penghargaan yang sifatnya tidak tetap atau sewaktu-waktu.

Mathis dan Jackson dalam Hidayah (2016), berpendapat bahwa pada dasarnya kompensasi dapat dikelompokan dalam dua kelompok, yaitu "kompensasi langsung dan kompensasi tidak langsung". Kompensasi langsung berupa gaji pokok dan gaji variabel, dan kompensasi tidak langsung berupa tunjangan, dengan penjelasan sebagai berikut : 


\section{Kerangka Pemikiran}

Gambar .1

Kerangka Pemikiran

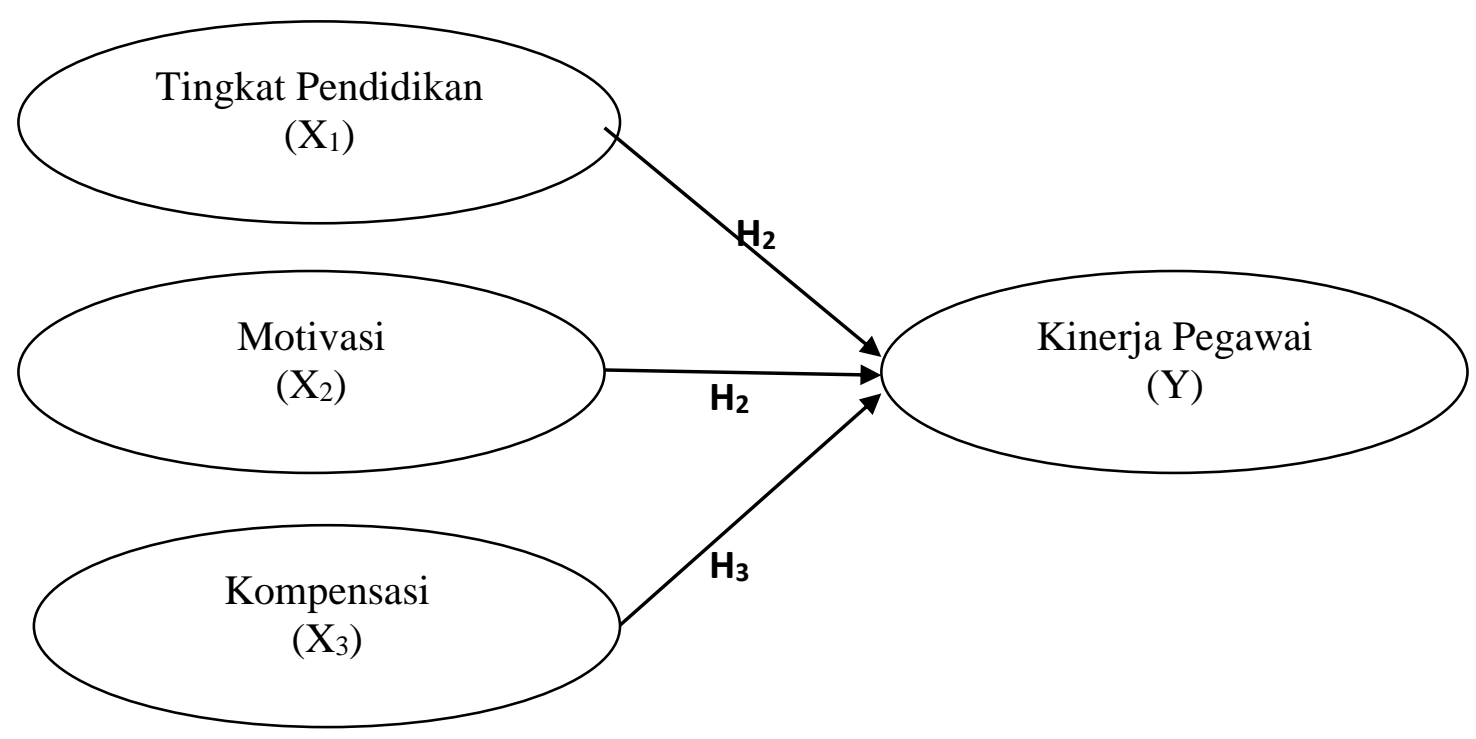

\section{Hipotesis.}

Hipotesis dalam penelitian ini adalah:

$\mathrm{H}_{1}$ : Tingkat pendidikan signifikan berpengaruh terhadap kinerja pegawai di BRI cab. Semarang A.Yani

$\mathrm{H}_{2}$ : Motivasi berpengaruh signifikan terhadap kinerja pegawai di BRI cab. Semarang A.Yani

$\mathrm{H}_{3}$ : Kompensasi berpengaruh signifikan terhadap kinerja pegawai di BRI cab. Semarang A.Yani

\section{METODOLOGI}

Dalam penelitian ini dignakan Metode Kuantitatif. Oleh Sugiyono (2009) Teknik Analisis Data digunakan untuk menjawab rumusan masalah, menguji hipotesis yang telah dirumuskan dalam penelitian. Alat analisis yang digunakan dalam menguji variabel dependen dan variabel independen adalah Analisis Regresi Linier Berganda (Multiple Regresion Analysis) namun agar memperoleh hasil yang maksimal perlu dilakukan Uji Asumsi Klasik sebagai gambaran yang akan digunakan untuk mengolah data. 
Analisis dan Pembahasan

6.1. Uji Validitas dan Realibilitas.

\section{Uji Validitas}

Uji validitas merupakan uji yang digunakan untuk mengukur pertanyaan dalam kuesioner yang digunakan betul-betul dapat mengukur apa yang hendak diukur (Ghozali, 2006). Suatu instrumen yang valid mempunyai validitas tinggi, sebaliknya instrumen yang kurang valid berarti memiliki validitas yang rendah.

Uji validitas dalam penelitian ini dengan menggunakan analisis korelasi product moment yang dikemukakan oleh Pearson. Uji validitas korelasi product moment dalam penelitian ini dilakukan dengan menggunakan program SPSS 23. Dengan kriteria pengujian jika korelasi antar butir dengan skor total diperoleh $p<0,05$ maka instrumen tersebut dinyatakan valid, atau sebaliknya jika korelasi antar butir dengan skor total diperoleh $p>0,05$ maka instrumen tersebut dinyatakan tidak valid (Sugiyono, 2009). Pada Tabel 1 dapat dilihat hasil uji validitas.

Berdasarkan perhitungan dengan SPSS, nilai R tabel untuk 60 responden adalah 0.254. hasil yang diperoleh lebih dari R tabel dan korelasi antar butir dengan skor total diperoleh $p<$ 0.05 yaitu 0.000 maka dapat disimpulkan bahwa instrumen dinyatakan valid.

\section{Uji Realibilitas.}

Uji ini untuk mengukur suatu kuesioner yang merupakan indikator dari variabel atau konstruk. Suatu kuesioner dikatakan reliabel jika jawaban seseorang terhadap pertanyaan adalah konsisten atau stabil dari waktu ke waktu (Ghozali, 2011). Suatu variabel dinyatakan reliabel jika Cronbach Alpa > 0,70 (Ghozali, 2011).

Hasil uji reliabilitas menunjukkan bahwa Cronbach Alpa variabel tingkat pendidikan, motivasi, kompensasi dan kinerja pegawai menunjukkan nilai lebih dari 0.70. Dengan demikian dapat disimpulkan bahwa semua variabel adalah reliabel dan layak untuk dilakukan pengujian selanjutnya.

\section{Asumsi Klasik}

Untuk menghindari terjadinya bias, data yang digunakan harus berdistribusi normal. Uji normalitas bertujuan untuk menguji apakah dalam model regresi variabel-variabel independen mempunyai distribusi normal atau tidak. Hal ini dikarenakan bahwa untuk 
penelitian yang menggunakan regresi linier berganda perlu diuji dengan uji normalitas data. Model regresi yang baik adalah memiliki distribusi normal (Ghozali, 2011).

Selain dengan normal probability plot, pendeteksian normalitas dapat dilakukan dengan uji statistik non parametric kolmogorof-smirnov (K-S) dengan level signoifikasi > 0,05. Dalam uji Kolmogrof Smirnov akan diuji normalitas residual dan normalitas variabel.

Dari uji kolmogrof smirnov menunjukan bahwa nilai Asymp 0,943 lebih besar dari 0,005. Hal ini berarti bahwa data residual terdistribusi normal.

\section{Uji Multikolonieritas}

Uji multikolonieritas bertujuan untuk menguji apakah dalam model regresi ditemukan adanya korelasi antar variabel bebas. Model regresi yang baik tidak terjadi korelasi antar variabel bebas. Hal ini dikarenakan dalam penelitian ini menggunakan 3 (tiga) variabel independen, sehingga perlu diuji apakah terdapat korelasi (hubungan) antara satu variabel independen dengan variabel independen yang lain. Untuk mendeteksi ada tidaknya multikolonearitas di dalam model regresi adalah dengan melihat nilai toleransi dan Variance Inflation Factor (VIF). Apabila nilai tolerance > 10\% dan nilai VIF < 10, maka dapat disimpulkan tidak ada multikolinieritas antar variabel bebas dalam model regresi.

Dari tabel perhitungan SPSS terlihat bahwa setiap variabel bebas mempunyai nilai tolerance $\geq 0,1$ dan nilai VIF $\leq 10$. Jadi dapat disimpulkan bahwa tidak ada multikolineritas antar variabel bebas dalam model regresi ini.

\section{Uji Heterokedastisitas}

Uji Heteroskedastisitas bertujuan menguji apakah dalam regresi terjadi ketidaksamaan variance dan residual suatu pengamatan ke pengamatan yang lain. Heteroskedastisitas digunakan dikarenakan penelitian ini menggunakan data coss section, dimana coss section menguji beberapa variabel (obyek) dalam satu waktu sehingga pengujian heteroskedastisitas diperlukan dalam penelitian ini. Cara mendeteksi ada atau tidaknya heteroskdastisitas yaitu dengan Uji Glejser. Uji Glejser mengusulkan untuk meregres nilai absolut residual terhadap variabel independen (Gujarati, 2003 dalam Ghozali, 2012). Jika variabel independen signifikan secara statistik mempengaruhi variabel dependen, maka ada indikasi terjadii heteroskedastisitas. Apabila probabilitas signifikansinya di atas tingkat kepercayaan 5\%. Jadi dapat disimpulkan model regresi tidak mengandung adanya heteroskedastisitas (Ghozali, 2011). 
Pada perhitungan SPSS menunjukkan bahwa nilai signifikan setiap variabel independen (Tingkat Pendidikan, Motivasi dan Kompensasi) diatas 0.05. hal ini dapat disampaikan tidak terjadi heteroskedastisitasnpada model regresi ini.

\section{Analisis Regresi Linier Berganda}

Pada dasarnya analisis regresi adalah studi mengenai 'ketergantungan variabel independen dengan variabel independen dengan tujuan untuk memprediksi rata-rata variabel dependen berdasarkan hasil variabel yang diketahui (Gujarati, 2003 dalam Ghozali, 2011). Berikut ini adalah hasil uji regresi linier berganda dalam penelitian ini:

Tabel 6.

Hasil Uji Regresi Linier Berganda

Coefficients $^{\mathrm{a}}$

\begin{tabular}{|c|c|c|c|c|c|c|c|c|}
\hline \multirow{2}{*}{\multicolumn{2}{|c|}{ Model }} & \multicolumn{3}{|r|}{$\begin{array}{c}\text { Standardize } \\
\mathrm{d} \\
\text { Coefficients } \\
\end{array}$} & \multirow[b]{2}{*}{$\mathrm{t}$} & \multirow[b]{2}{*}{ Sig. } & \multicolumn{2}{|c|}{$\begin{array}{c}\text { Collinearity } \\
\text { Statistics }\end{array}$} \\
\hline & & B & $\begin{array}{l}\text { Std. } \\
\text { Error }\end{array}$ & Beta & & & $\begin{array}{c}\text { Toleranc } \\
\mathrm{e}\end{array}$ & VIF \\
\hline \multirow[t]{4}{*}{1} & (Constant) & -1.455 & 1.835 & & -.793 & .431 & & \\
\hline & $\begin{array}{l}\text { Tingkat } \\
\text { Pendidikan } \\
\text { (X1) }\end{array}$ & .490 & .078 & .505 & 6.314 & .000 & .821 & 1.218 \\
\hline & $\begin{array}{l}\text { Motivasi } \\
\text { (X2) }\end{array}$ & .143 & .066 & .175 & 2.160 & .035 & .799 & 1.252 \\
\hline & $\begin{array}{l}\text { Kompensasi } \\
\text { (X3) }\end{array}$ & .462 & .090 & .408 & 5.108 & .000 & .824 & 1.214 \\
\hline
\end{tabular}

a. Dependent Variable: Kinerja Pegawai (Y)

Sumber : Data primer yang diolah, 2017

Dari hasil analisis dengan SPSS 23 tersebut, maka dapat diketahui persamaan regresi dari penelitian ini. Adapun persamaan regresi linier yang terbentuk adalah:

$\mathrm{Y}=$ 0,505 Tingkat Pendidikaan + 0,175 Motivasi + 0,408 Kompensasi

Daripersamaan regresi linier berganda diatas maka dapat dianalisis sebagai berikut:

a. Koefisien regresi Tingkat Pendidikan sebesar 0,505. Koefisien bertanda positif, berarti bahwa setiap kenaikan tingkat pendidikan akan diikuti dengan kenaikan kinerja pegawai. 
b. Koefisien regresi Motivasi sebesar 0,175. Koefisien bertanda positif, berarti bahwa setiap kenaikan motivasi akan diikuti dengan peningkatan kinerja pegawai

c. Koefisien regresi Kompensasi sebesar 0,408. Koefisien bertanda positif, berarti bahwa setiap kompensasi akan diikuti dengan kenaikan kinerja pegawai.

\section{Uji Hipotesis}

\section{Uji t}

Uji hipotesis, iju t bertujuan untuk mengetahui besarnya pengaruh masing-masing variabel independen secara parsial terhadap variabel dependen. Nilai dari uji t dilihat $p$-value (pada kolom sig) pada masing-msing variabel independen. Jika nilai $p$-value lebih kecil dari level of signifikan 0,05 maka hipotesis diterima. Hasilnya sebagai berikut:

\section{Tabel 7.}

\section{Hasil Uji t}

Coefficients $^{\mathrm{a}}$

\begin{tabular}{|c|c|c|c|c|c|c|c|c|}
\hline & & $\begin{array}{r}\text { Unstand } \\
\text { Coeffi }\end{array}$ & $\begin{array}{l}\text { ardized } \\
\text { ients }\end{array}$ & $\begin{array}{l}\text { Standardize } \\
\mathrm{d} \\
\text { Coefficients }\end{array}$ & & & $\begin{array}{r}\text { Colline } \\
\text { Statis }\end{array}$ & $\begin{array}{l}\text { rity } \\
\text { cs }\end{array}$ \\
\hline & & B & $\begin{array}{l}\text { Std. } \\
\text { Error }\end{array}$ & Beta & $\mathrm{t}$ & Sig. & $\begin{array}{c}\text { Toleranc } \\
\mathrm{e}\end{array}$ & VIF \\
\hline 1 & (Constant) & -1.455 & 1.835 & & -.793 & .431 & & \\
\hline & $\begin{array}{l}\text { Tingkat } \\
\text { Pendidikan } \\
\text { (X1) }\end{array}$ & .490 & .078 & .505 & 6.314 & .000 & .821 & 1.218 \\
\hline & $\begin{array}{l}\text { Motivasi } \\
\text { (X2) }\end{array}$ & .143 & .066 & .175 & 2.160 & .035 & .799 & 1.252 \\
\hline & $\begin{array}{l}\text { Kompensasi } \\
\text { (X3) }\end{array}$ & .462 & .090 & .408 & 5.108 & .000 & .824 & 1.214 \\
\hline
\end{tabular}

a. Dependent Variable: Kinerja Pegawai (Y)

Sumber : Data primer yang diolah, 2017

\section{Uji F ( Goodness Of Fit Model )}

Uji statistik F pada dasarnya menunjukan apakah semua variabel bebas (Tngkat Pendidikan, Motivasi dan Konpensasi) yang dimasukan dalam model mempunyai pengaruh secara bersama-sama terhadap variabel terikat. Untuk menguji apakah model linier tersebut sudah tepat atau belum, maka dilihat membandingkan probabilitas dari hasil perhiyungan uji 
F. Jika menunjukan nilai probabilitas menunjukan nilai <0,05 maka model dalam regresi tersebut merupakan model yang fit. Berikut adalah hasil uji F.

Tabel 8.

Hasil Uji F

ANOVA $^{b}$

\begin{tabular}{llrrrrr}
\hline Model & & Sum of Squares & df & Mean Square & F & Sig. \\
\hline 1 & Regression & 177.286 & 3 & 59.095 & 44.692 & $.000^{\mathrm{a}}$ \\
& Residual & 74.048 & 56 & 1.322 & & \\
& Total & 251.333 & 59 & & & \\
\hline
\end{tabular}

a. Predictors: (Constant), Kompensasi (X3), Tingkat Pendidikan (X1), Motivasi (X2)

b. Dependent Variable: Kinerja Pegawai (Y)

Sumber : Data primer yang diolah, 2017

Berdasarkan Tabel 4.16 nilai $\mathrm{F}$ hitung sebesar 44.692 dengan tingkat signifikan $0.000<0,05$. Sehingga dapat disimpulkan bahwa model tersebut merupakan model yang fit.

\section{Koefisien Determinasi}

Koefisien determinasi pada intinya adalah mengukur seberapa jauh kemampuan model pada variabel bebas (X) dalam menerangkan variabel terikat (Y), (Ghozali, 2011). Berikut adalah hasil uji Koefisien Tingkat Pendidikan, Motivasi, Kompensasi terhadap Kinerja Pegawai.

Tabel 9.

\section{Hasil Uji Koefisien Determinasi}

Model Summary ${ }^{\mathrm{b}}$

\begin{tabular}{|l|r|r|r|r|r|}
\hline Model & \multicolumn{1}{|c|}{$\mathrm{R}$} & R Square & $\begin{array}{c}\text { Adjusted R } \\
\text { Square }\end{array}$ & $\begin{array}{c}\text { Std. Error of } \\
\text { the Estimate }\end{array}$ & Durbin-Watson \\
\hline 1 & $.840^{\mathrm{a}}$ & .705 & .690 & 1.150 & 1.709 \\
\hline
\end{tabular}

a. Predictors: (Constant), Kompensasi (X3), Tingkat Pendidikan (X1), Motivasi (X2)

b. Dependent Variable: Kinerja Pegawai (Y)

Sumber : Data primer yang diolah, 2017

Nilai koefisien determinasi adalah antara nol dan satu. Nilai $\mathrm{R}^{2}$ yang kecil berarti kemampuan variabel independen dalam menjelaskan variabel dependen sangat terbatas. Nilai yang mendekati satu berarti variabel independen memberikan hampir semua informasi yang dibutuhkan dalam memprediksi variabel dependen (Ghozali, 2011). Ada kelemahan yang 
mendasar dalam penggunaan koefisien determinasi yaitu bias terhadap jumlah variabel independen yang dimasukan ke dalam model. Setiap ada tambahan satu variabel independen maka $\mathrm{R}^{2}$ pasti akan meningkat tanpa peduli apakah variabel tersebut berpengaruh secara signifikan terhadap variabel dependen atau tidak.

Dari tabel 9. diatas, angka koefisien determinasi (Adjusted $R$ Square) sebesar 0,690. Hal ini berarti bahwa variabel Tingkat Pendidikan, Motivasi, dan Kompensasi mempunyai peranan 69,0\% secara bersama-sama untuk dapat menjelaskan atau menerangkan variabel Kinerja Pegawai. Sedangkan sisanya sebesar 31,0\% (100\% - 69\%) dijelaskan oleh variabel lain yang mempengaruhi Kinerja Pegawai.

\section{KESIMPULAN}

Berdasarkan hasil penelitian ini, maka kesimpulan yang dapat diambil adalah :

1. Faktor pendidikan, motivasi dan kompensasi terbukti secara parsial berpengaruh secara signifikan terhadap kinerja pegawai di BRI Cab. Semarang A.Yani. Variabel tingkat pendidikan lebih dominan dengan nilai 6.314 dibandingkan variabel kompensasi dengan nilai 5.108 dan variabel motivasi dengan nilai 2.160.

2. Untuk hasil uji secara simultan, ketiga faktor independen yaitu tingkat pendidikan, motivasi dan kompensasi berpengaruh secara signifikan terhadap kinerja pegawai BRI Cab. Semarang A.Yani.

3. Untuk hasil uji koefisien determinasi (R2) menunjukan kinerja pegawai BRI Cab. Semarang A.Yani dipengaruhi oleh variabel pendidikan, motivasi dan kompensasi sebesar 69,0\%. Sedangkan sisanya yaitu 31,0\% dipengaruhi oleh sebab-sebab lain yang tidak diteliti dalam penelitian ini. 


\section{DAFTAR PUSTAKA}

Adhanari, Maria Asti. 2011. Pengaruh Tingkat Pendidikan terhadap Produktivitas Kerja Karyawan Bagian Produksi pada Maharani Handichaft di Kabupaten Bantul. Skripsi. Universitas Negeri Semarang

Ghozali, Imam. 2005. Aplikasi Analisis Multivariate dengan progam SPSS. Edisi ketiga. Semarang: Badan Penerbit Universitas Diponegoro

Ghozali, Imam. 2011. Aplikasi Analisis Multivariate dengan progam SPSS. Semarang: Badan Penerbit Universitas Diponegoro

Hapsari, Wahyu Fitri. 2012. Pengaruh Gaya Kepemimpinan Transformasional Kepala Sekolah dan Tingkat Gaji Guru terhadap Motivasi Kerja Guru SMA Negeri di Kabupaten Purworejo. Skripsi. Universitas Negeri Yogyakarta

Hasibuan, SP. Malayu. 2006. Manajemen Sumber Daya Manusia. Jakarta: Bumi Askara.

Hasibuan, SP. Malayu. .2008.Manajemen Sumber Daya Manusia.Jakarta: Bumi Askara

Hendri, Edduar. 2013. Analisis Faktor-Faktor yang Mempengaruhi Kinerja Pegawai pada Fakultas Ekonomi Universitas PGRI Palembang. Jurnal Media Wahana Ekonomika, Vol.10, No. 3, Oktober $2013: 23-42$

Hidayah, Nurul. 2016. Pengaruh Kompensasi terhadap Kinerja Karyawan melalui Kepuasaan Kerja sebagai Variabel Intervening. Skripsi. Universitas Negeri Yogyakarta.

Manik, Sudarmin. 2016. Faktor-Faktor yang Mempengaruhi Pemberian Kompensasi Pada Karyawan Bank. Jurnal Lembaga Keuangan dan Perbankan- Volume 1, Nomor 2, JuliDesember 2016

Masria'ah. 2016. Pengaruh Kepuasan Kerja, Komitmen Organisasi dan Kepemimpinan terhadap Turnover Intention pada PT Lohongka. Skripsi. Sekolah Tinggi Ilmu Ekonomi Semarang

Sardiman, A.M.2006.Interaksi dan Motivasi Belajar Mengajar.Jakarta:Grafindo

Sugiyono. 2010. Metode Penelitian Bisnis. Bandung: Alfabeta

Undang-Undang No. 20 Tahun 2003 tentang Sistem Pendidikan Nasional

Vionita, Vevi Gusrini. 2013. Pengaruh Tingkat Pendidikan dan Motivasi Kerja terhadap Kinerja Pegawai Tata Usaha SMK Negeri di Kota Payakumbuh. Skripsi. Universitas Negeri Padang 